\title{
Maatalousympäristöjen ekosysteemipalvelut: kysyntä, tarjonta ja politiikkaohjaus
}

\author{
Annika Tienhaara ${ }^{1}$,Emmi Haltia ${ }^{2}$, Eija Pouta ${ }^{1}$, Kyösti Arovuori ${ }^{2}$ \\ 1)Luonnonvarakeskus, Latokartanonkaari 9,00790 Helsinki, annika.tienhaara@luke.fi \\ 2) Pellervo taloustutkimus PTT, Eerikinkatu28, 00101 Helsinki
}

\section{Tiivistelmä}

Ekosysteemipalveluiden huomioonottaminen maatalouden ympäristöpolitiikan suunnittelussa on olennaista. Tässä tutkimuksessa tuotetaan kansalais- ja viljelijäkyselyihin pohjautuen tietoa ekosysteemipalveluiden kysynnän ja tarjonnan kohtaamisesta. Ekosysteemipalveluita, joita kansalaiset pitävät tärkeinä, mutta joiden tuotannossa koetaan olevan parantamisen varaa, ovat kasveja pölyttävien hyönteisten säilyminen, maisema, luonnontilaisten kasvi- ja eläinlajien sekä ekosysteemien säilyminen maatalousympäristössä sekä maatalouden kulttuuriperintö. Viljelijöiden kiinnostus kohdistuu erityisesti maatalousmaan tuottokyvyn ylläpitämiseen. Koska viljelijöiden kiinnostus on korkealla tasolla, kohtuullisen pienellä politiikkasysäyksellä voidaan saada aikaan paljon tuloksia. Lisäksi maaperän tuottokyky liittyy moniin muihin ekosysteemipalveluihin, joten parantamalla tuottokykyä voidaan samalla muun muassa vähentää ravinteiden huuhtoutumista ja lisätä hiilen sitoutumista maatalousmaahan. Lähes 30 prosenttia viljelijöistä oli valmiita tuottamaan ekosysteemipalveluita kansalaisten keskimääräistä maksuhalukkuutta alemmalla korvaustasolla. Tuotannon tukea voitaisiinkin kohdentaa erityisesti näille viljelijöille. Näin osa viljelijöistä valitsisi tuotantosuunnakseen ekosysteemipalveluiden tuotannon, esimerkiksi maisemapalvelut tai biodiversiteetin.

Asiasanat: hyötylähtöinen maatalouden ympäristöpolitiikka, ekosysteemipalvelut, arvottaminen 


\section{Johdanto}

Ekosysteemipalvelut ovat luonnon palveluja ja tuotteita, jotka tukevat ihmisen olemassaoloa ja hyvinvointia (TEEB 2010). Ne voivat olla aineellisia tai aineettomia hyötyjä. Maailmanlaajuisesti on todettu, että ekosysteemipalveluiden tarjonta on heikentynyt viimeisten 50 vuoden aikana olennaisesti vähentäen myös ihmisen hyvinvointia. Maatalouden ekosysteemit tuottavat hyvinvoinnin kannalta välttämättömiä palveluita, joihin liittyy merkittäviä arvoja. Siksi niiden huomioon ottaminen on tärkeää maatalouden käytännöissä ja politiikkaohjauksessa.

Ekosysteemien toiminnot, mukaan lukien luonnon monimuotoisuus, luovat ekosysteemipalveluita yhdessä ihmisen tarjoamien tuotantopanosten kanssa. Aiempaa tutkimustietoa maatalousympäristöjen tuottamista ekosysteemipalveluista on koottu Luonnonvarakeskuksen sivuille (luke.fi). Maatalousympäristöjen tuotantopalvelut, kuten ruoka ja kuitu, sekä niiden arvo tunnetaan hyvin. Sen sijaan sääntely- ja kulttuuripalveluista ja niiden arvosta ei ole ollut selkeää kuvaa.

On esitetty, että ekosysteemipalvelut tulisi ottaa maatalouspolitiikassa paremmin huomioon, jolloin ruoan ohella myös aineettomien ekosysteemipalvelujen tila olisi kiinnostuksen kohteena. Ekosysteemipalveluiden tuotanto voitaisiin järjestää hyötylähtöisellä maatalouden ympäristöpolitiikalla, jolloin viljelijöille maksettaisiin esimerkiksi maisemaan, monimuotoisuuteen, valuma-alueiden toimintaan ja hiilivarastoihin liittyvistä ekosysteemipalveluista. Monipuolisen ekosysteemipalvelujen tuotannon voidaan olettaa olevan osalle viljelijöistä kiinnostava haaste. Maatalouden ekosysteemipalvelut eivät ole pelkästään elinkeinon ja hallinnon välinen asia. Useiden ekosysteemipalveluiden kysyntä ja arvo muodostuvat ihmisten kokemuksen kautta. Suuri osa maatalousympäristöjen ekosysteemipalveluista on julkishyödykkeitä, joilla ei ole markkinoita, ja näin ollen niiden arvon huomioon ottaminen edellyttää tutkimustietoa.

Suomessa ei ole aiemmin toteutettu tutkimusta, jossa olisi arvioitu kokonaisuutena maatalousympäristöjen ekosysteemipalveluiden kysyntää ja tarjontaa, vaan monia maatalousympäristöjen ekosysteemipalveluja on arvotettu erillisinä (Arovuori ja Saastamoinen 2013). Esimerkiksi Grammatikopoulou ym. (2012a, 2013) tuottavat tietoa maatalousmaiseman arvoista erilaisilla hoito-ohjelmilla. Ahtiainen ja Pouta (2011) sekä Tienhaara ym. (2013) ovat arvottaneet maatalouden geenivaroihin liittyviä ekosysteemipalveluita. Maanomistajien halukkuutta ekosysteemipalvelujen tuottamiseen on mitattu liittyen maisemapalveluihin (Grammatikopoulou ym. 2013). Kokeilun muodossa on tarkasteltu peltomaan ekosysteemipalveluiden kehittämistä tarjouskilpailun avulla (Iho ym. 2014) ja tuotettu tietoa viljelijöiden halukkuudesta osallistua yhden ekosysteemipalvelun tuotantoon (Grammatikopoulou ym. 2012b).

Tämän tutkimuksen tavoitteena on tuottaa tietoa maatalousympäristöjen ekosysteemipalveluiden kysynnästä ja tarjonnasta sekä ekosysteemipalveluiden huomioonottamisesta maatalouspolitiikan kehittämisessä ja arvioinnissa.

\section{Menetelmät}

Kansalaisten ja viljelijöiden näkemyksiä maatalouden ekosysteemipalveluista kartoitettiin kyselytutkimuksen avulla. Kansalaiskysely toteutettiin keväällä 2016 Taloustutkimuksen internet-paneelin avulla ja kyselyyn vastasi 2066 vastaajaa (vastausprosentti $25 \%$ ). Viljelijöille kohdistettuun kyselyyn vastasi 1212 viljelijää (vastausprosentti $12 \%$ ) tammikuussa 2017. 
Kyselyillä selvitettiin mielipiteitä muun muassa Suomen maatalouden merkityksestä, maatalouden ympäristöohjelmasta sekä maatalouden ympäristö-vaikutuksista. Lisäksi valintakoemenetelmän avulla tutkittiin kansalaisten halukkuutta tukea uutta ympäristöhyötyjä painottavaa maatalouden ympäristöohjelmaa sekä viljelijöiden halukkuutta osallistua siihen. Valintakoemenetelmässä luodaan kuvitteelliset markkinat ja vastaajille esitetään erilaisia valintatilanteita, joissa heidän tulee valita kahden tai useamman vaihtoehdon välillä. Eri vaihtoehtoja kuvataan ominaisuuksien avulla, joiden tasot vaihtelevat vaihtoehtojen välillä. Sisällyttämällä rahamääräinen muuttuja ominaisuuksien joukkoon, vastaajien maksuhalukkuus (WTP) tai korvauksen hyväksymishalukkuus (WTA) tietystä attribuutin tasosta voidaan määrittää heidän tekemiensä valintojen perusteella. Valintakokeessa esitettiin vastaajille kolme vaihtoehtoa, joissa oli mukana myös status quo -vaihtoehto (nykyinen ohjelma). Kullakin vaihtoehtoisella ohjelmalla oli neljä ominaisuutta: biodiversiteetti, maisema, ilmastonmuutoksen torjuminen sekä veden laatu. Ominaisuuksien tila esitettiin kolmen tason avulla: nykytila sekä pienempi ja suurempi parannus ympäristön tilassa. Kullekin vastaajalle esitettiin kuusi valintatilannetta. Valintatilanteisiin kuului myös rahamääräinen muuttuja: kansalaisilla kustannus tuloveron korotuksena vuosina 2017-2026 ja viljelijöillä ympäristökorvaus per ha/vuosi vuosina 2021-

2027. Valintakokeen lisäksi kansalaiskyselyssä oli osio halukkuudesta ostaa ekosysteemipalvelulähtöisesti tuotettua ruokaa.

Kyselyiden tulosten valmistuttua järjestettiin sidosryhmätyöpaja. Työpajaan kutsuttiin hallinnon ja muiden sidosryhmien edustajia sekä viljelijöitä. Tilaisuudessa esiteltiin kyselyiden tuloksia sekä hyötylähtöistä, ekosysteemipalveluiden tuottamiseen perustuvaa ympäristöpolitiikkaa. Osallistujat keskustelivat pienryhmissä maatalouden ekosysteemipalveluiden kysynnän ja tarjonnan tulevaisuuden näkymistä ja siitä, voitaisiinko tarjontaa tulevaisuudessa turvata hyötylähtöisellä politiikalla.

\section{Tulokset}

\section{Ekosysteemipalveluiden kysyntä ja arvo}

Kyselyyn vastanneet kansalaiset arvioivat maatalousympäristön ekosysteemipalveluiden tärkeyttä ja Suomen maatalouden onnistumista näiden ekosysteemipalveluiden tuotannossa (Kuva 1). Keskeisimmäksi palveluksi nousi riittävä laadukkaan ruoan tuotanto ja tässä maatalouden katsottiin myös onnistuneen hyvin. Tärkeitä ekosysteemipalveluita, joiden tuotantoon ei oltu tyytyväisiä, olivat luontaisten lajien ja ekosysteemien säilyminen ja kasveja pölyttävien hyönteisten runsaus. Lisäksi maatalouden maisemaa arvostettiin ekosysteemipalveluna, mutta myös sen laadussa katsottiin olevan parantamisen varaa.

Maatalouden ympäristövaikutuksista keskeisimmiksi asennetasolla koettiin vesistövaikutukset, joita 68 prosenttia vastaajista piti erittäin tärkeinä. Lähes puolet vastaajista piti myös lajien säilymiseen liittyviä ja ilmastovaikutuksia erittäin tärkeinä.

Kansalaiset tekivät kyselyssä valintoja erilaisten ekosysteemipalveluja tuottavien ympäristöohjelmien välillä (valintakoemenetelmä). Valintojen pohjalta nähtiin, että ekosysteemipalveluihin ja ympäristöohjelmiin liittyvät mieltymykset erosivat ja että niiden perusteella kansalaiset voitiin jakaa ryhmiin (laten class model). Vastaajien preferenssien oletettiin olevan samankaltaiset ryhmän sisällä, mutta eroavan eri vastaajaryhmien välillä. Aineistosta tunnistettiin viisi erilaista vastaajaryhmää: ympäristölähtöiset, puntaroijat, kustannusherkät, nykytilan kannattajat sekä satunnaiset. Ryhmien pääpiirteet on esitetty Kuvassa 2. 


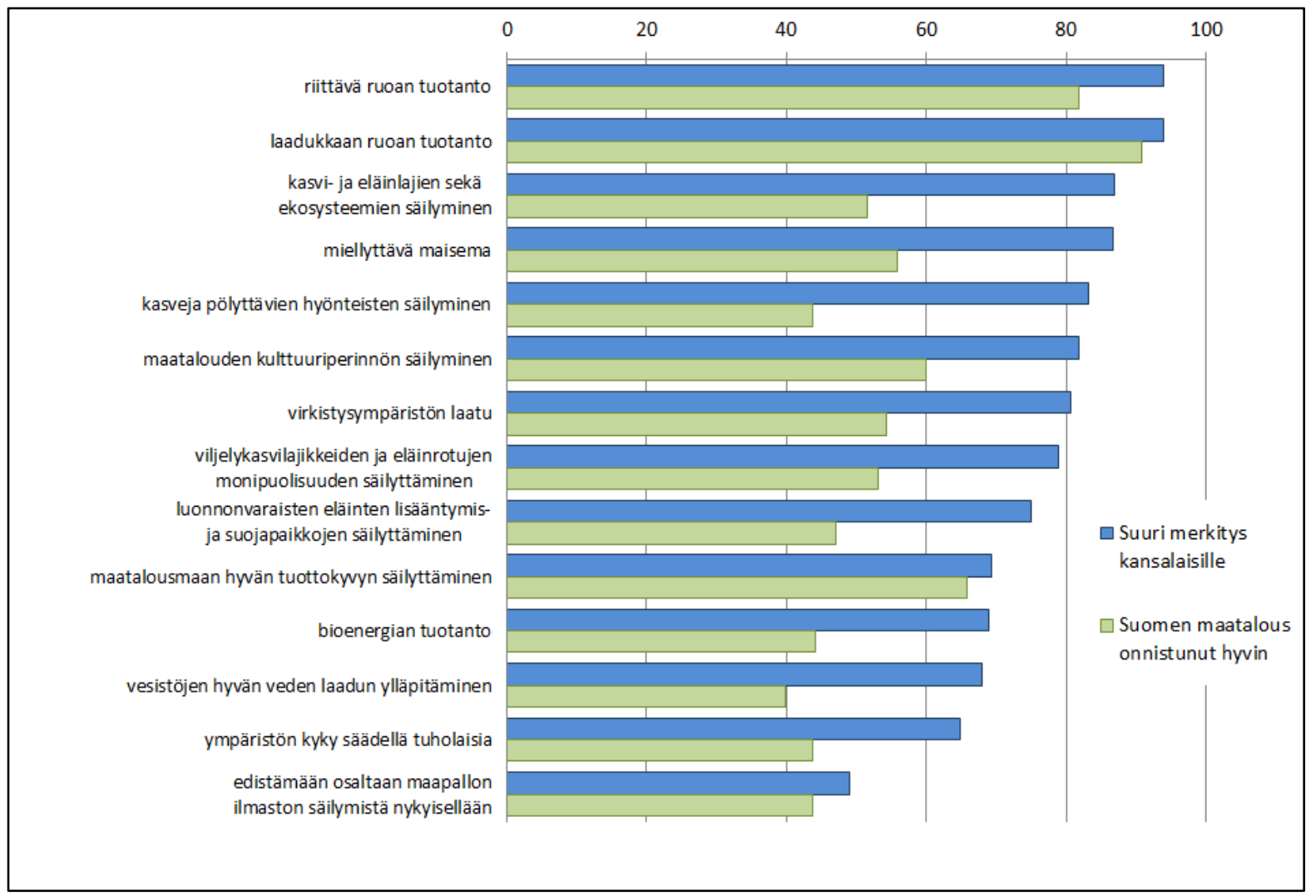

Kuva 1. Kansalaisten tärkeiksi kokemat ekosysteemipalvelut ja tyytyväisyys niiden tuotantoon.

\section{Ympäristölähtöiset, 34\%}

- Kannattavat uuden tyyppistä ohjelmaa

- Kustannusten vaikutus vähäinen

- $\quad$ Erityisesti monimuotoisuus ja ilmastopäästöjen vähennykset ovat tärkeitä

\section{Kustannusherkät, $17 \%$}

- Lähinnä kustannukset vaikuttavat

- Veden laadulla ja maisemalla (kasvit) merkitystä

\section{Puntaroijat, $31 \%$}

- Kustannuksia punnitaan

- Erityisesti veden laadulla ja maisemalla (eläimet) merkitystä

\section{Nykytilan kannattajat, $9 \%$}

- Eivät kannata uusia ohjelmia

\section{Satunnaiset, $8 \%$}

- Valinnoista ei löydy juurikaan johdonmukaisuutta

Kuva 2. Kansalaiset jaettiin viiteen ryhmään erilaisia ekosysteemipalveluja tuottavien ympäristöohjelmien arvioinnin perusteella. 
Ekosysteemipalvelut olisi mahdollista valjastaa nykyistä tehokkaammin ruoan tuotannossa. Kuluttajat voivat esimerkiksi arvostaa torjunta-aineetonta tuotantoa ja olla valmiita maksamaan enemmän ruoasta, jonka tuotantoon on käytetty luontaisia torjujia. Kansalaiskyselyssä suosituimpia ekosysteemipalveluja tehokkaammin hyödyntäviä tuotantotapoja olivat maan ravinnetasapainoon ja vesiensuojeluun liittyvät tuotantotavat. Näitä olivat muun muassa mahdollisimman tarkoituksenmukainen lannoitteiden käyttö vesien suojelun tehostamiseksi, karjanlannan tehokkaampi käyttö keinolannoitteiden asemasta maan tuottokyvyn ylläpitämiseksi ja typensitojakasvien, kuten apilan ja herneen, käyttö keinolannoituksen täydentäjänä.

Halukkuus ostaa mainituilla tuotantotavoilla tuotettua ruokaa - mahdollisesta kalliimmasta hinnasta huolimatta - liittyi erityisesti typensitojiin, luontaisiin torjujiin ja monimuotoisuuskaistoihin. Ostohalukkaat olivat tyypillisesti naisia, korkeasti koulutettuja ja korkeampituloisia ylempiä toimihenkilöitä. Myös maaseudulla sekä Itä- ja Pohjois-Suomessa asuminen liittyivät ostohalukkuuteen. Vastaajista jopa 43 prosenttia oli halukkaita ostamaan valitsemillaan tuotantotavoilla tuotettua ruokaa, vaikka se olisi tavanomaista kalliimpaa. Korkeamman hinnan hyväksyvillä kuluttajilla mediaanimaksuhalukkuus oli 16 prosenttia tavanomaista korkeampi. Kuluttajista $28 \%$ prosenttia oli valmiita maksamaan viidenneksen korkeampaa hintaa tai enemmän. Maksuhalukkuutta löytyi erityisesti ylempientoimihenkilöiden ja alle 35-vuotiaiden kuluttajien keskuudesta. Ympäristötietoisuus, jota kuvasi esimerkiksi luonnonsuojelujärjestöjen jäsenyys, lisäsi sekä osto- että maksuhalukkuutta.

\section{Viljelijöiden kiinnostus ekosysteemipalveluiden tuotantoa kohtaan}

Viljelijäkyselyn perusteella erityisesti miellyttävän maiseman luominen ja hyvän veden laadun ylläpitäminen on toteutunut hyvin vastaajan omalla tilalla (Kuva 3). Heikoiten on onnistuttu bioenergian tuotannossa, ympäristön kyvyssä säädellä tuholaisia ja tilalla kasvatettavien eläinrotujen monipuolisuudessa. Eläinrotujen monipuolisuus oli ainoa ekosysteemipalvelu, jossa Suomen maatalouden nähtiin yleisesti onnistuneen paremmin kuin miten omalla tilalla on onnistuttu. Kaikkien muiden ekosysteemipalveluiden osalta oman tilan tilanne arvioitiin huomattavasti useammin hyväksi kuin tilanne Suomen maataloudessa yleisesti.

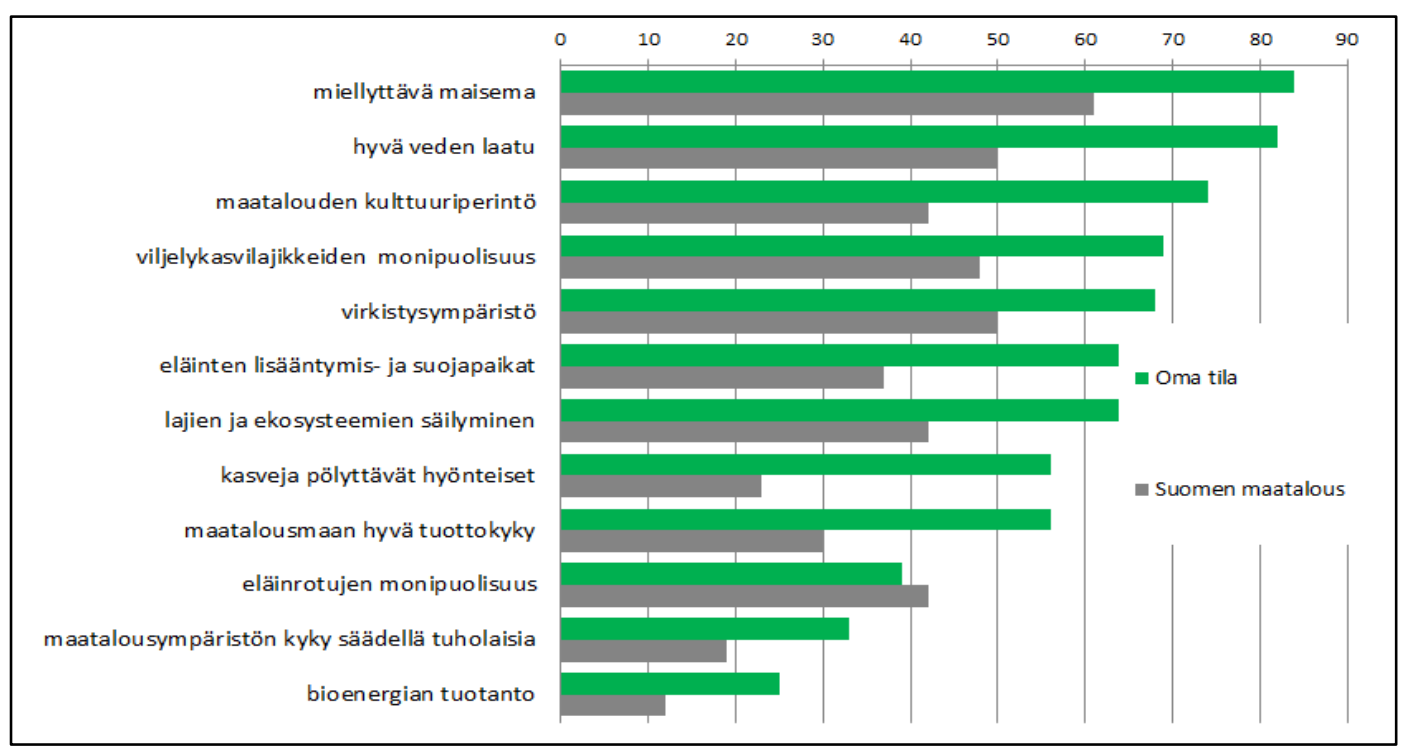

Kuva 3. Viljelijöiden näkemys siitä, kuinka hyvin eri ekosysteemipalveluiden tarjonta toteutuu heidän omalla tilallaan ja Suomen maataloudessa yleisesti (osuus vastaajista, joiden mukaan onnistunut erittäin tai melko hyvin). 
Viljelijöillä oli kyselyn perusteella mahdollisuuksia parantaa tilallaan erityisesti maatalousmaan tuottokykyä ja bioenergian tuotantoa (Kuva 4). Vähiten mahdollisuuksia parannuksiin nähtiin luonnonvaraisten eläinten lisääntymis- ja suojapaikkojen lisäämisessä ja tilalla kasvatettavien eläinrotujen monipuolistamisessa.

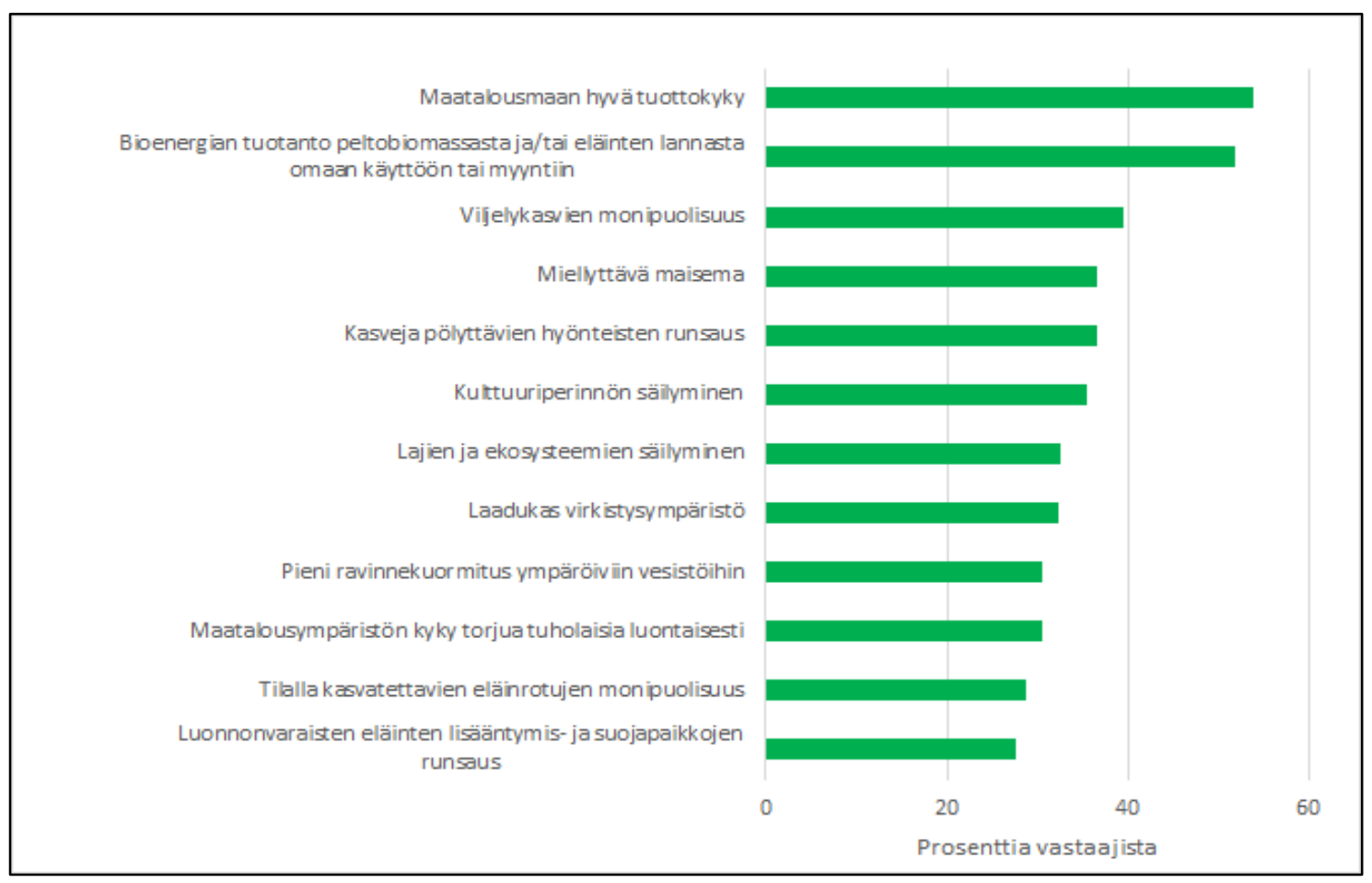

Kuva 4. Osuus viljelijöistä, joilla mielestään on tilallaan mahdollisuuksia lisätä ekosysteemipalveluiden tarjontaa.

Viljelijöistä 82 prosenttia oli halukkaita pienentämään tilansa ravinnehuuhtoumaa korvausta vastaan (Taulukko 1). Myös monivuotisten kasvien viljelypinta-alan lisääminen korvausta vastaan oli suosittua ja siihen oli halukkaita 76 prosenttia viljelijöistä. Perinnebiotooppien tarjontahalukkuus oli vähäisintä, mutta lähes puolet viljelijöistä oli halukkaita myös siihen. Kasvinviljely ja kotieläintilat eivät eronneet toisistaan halukkuudessa tarjota maisemaan liittyviä ekosysteemipalveluita ja perinnebiotooppeja. Sen sijaan kasvinviljelytiloilla oli kotieläintiloja enemmän halukkuutta lisätä monivuotisten kasvien pintaalaa ja pienentää ravinnehuuhtoumaa.

Taulukko 1. Viljelijöiden halukkuus tarjota ekosysteemipalveluita korvausta vastaan.

\begin{tabular}{|lc|}
\hline Ekosysteemipalvelu & Osuus viljelijöistä \\
\hline Maisema / Laidunnus & $53 \%$ \\
\hline Monivuotisten kasvien pinta-ala & $76 \%$ \\
Ravinnehuuhtouman pienentäminen & $82 \%$ \\
\hline Perinnebiotooppien lisääminen & $46 \%$
\end{tabular}




\section{Kohtaavatko ekosysteemipalveluiden kysyntä ja tarjonta?}

Kansalaisten maksuhalukkuutta ja viljelijöiden kompensaatiovaatimusta eri ekosysteemipalveluista verrattiin suppeammalla (taso 1) ja laajemmalla (taso 2) tarjonnan tasolla. Molemmat tasot kasvattivat ekosysteemipalveluiden tarjontaa nykyisestä. Kuvassa 5 on esitetty kansalaisten aggregoitu maksuhalukkuus (WTP) ja viljelijöiden aggregoitu kompensaation hyväksymishalukkuus (WTA) kunkin ekosysteemiattribuutin molemmille tasoille. Luonnon monimuotoisuudelle on suuri kysyntä, etenkin tasolla 1, mutta siihen kohdistuu viljelijöiden puolelta suuri korvausvaatimus. Myös veden laatua koskevat viljelijöiden kompensaatiovaatimukset ovat noin kaksi- tai kolminkertaiset kansalaisten maksuhalukkuuteen verrattuna. WTP ja WTA estimaatit alemmalle ilmastovaikutusten tasolle sekä eläimille maisemassa ovat lähempänä toisiaan. Kansalaisten maksuhalukkuus jopa ylittää korvausvaatimuksen maisema-attribuutin alemmalla tasolla.

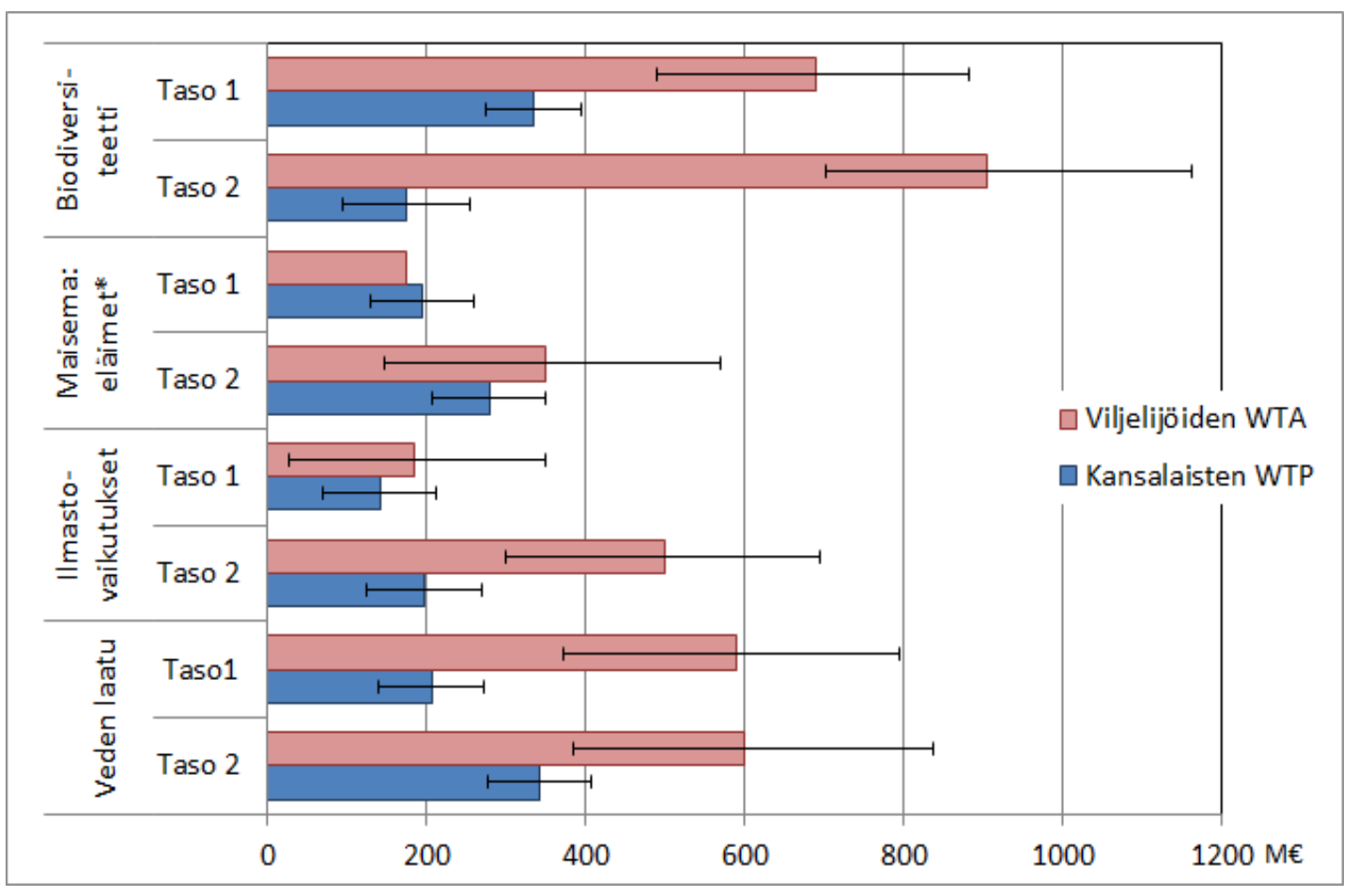

Kuva 5. Kuluttajien maksuhalukkuus (WTP) ja viljelijöiden kompensaatiovaatimus (WTA) eri ekosysteemipalveluista.

Viljelijöiden kompensaatiovaatimuksia verrattiin kansalaisten maksuhalukkuuteen myös niin, että kansalaisten kokonaismaksuhalukkuus jaettiin ympäristökorvausjärjestelmän piirissä olevien hehtaarien määrällä. Näin saatiin keskimääräinen, hehtaarikohtainen maksuhalukkuus, jota voidaan verrata suoraan viljelijöiden kompensaatiovaatimuksen jakaumaan. Kansalaisten keskimääräinen, hehtaarikohtainen maksuhalukkuus oli 445 euroa korkeimman hyöty-kustannus -suhteen mukaiselle ympäristöohjelmalle, jossa biodiversiteetti, maisema ja ilmastovaikutukset ovat suppealla tasolla ja veden laatu laajemmalla tasolla. Viljelijöistä 27 prosentilla oli tätä matalampi kompensaatiovaatimus, eli he olisivat valmiita toteuttamaan ohjelmaa kansalaisten maksuhalukkuuden mukaisella korvaussummalla (Kuva 6). 


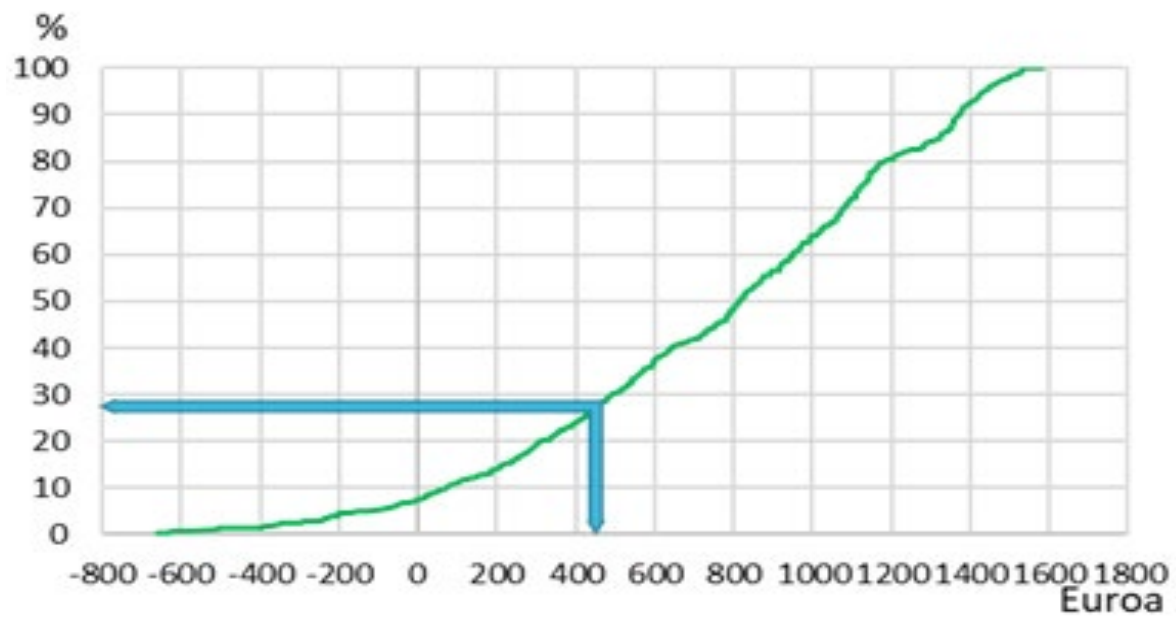

Kuva 6. Viljelijöiden kompensaatiovaatimuksen jakauma (vihreä viiva) ja kansalaisten keskimääräinen hehtaarikohtainen maksuhalukkuus (sininen viiva).

\section{Hyötylähtöinen politiikka}

Viljelijöille suunnatussa kyselytutkimuksessa kysyttiin viljelijöiden näkemyksiä nykyisen ympäristökorvausjärjestelmän mukaisesta ohjelmasta ja ehdotetusta uudesta, hyötylähtöisestä ympäristöpolitiikasta (Kuva 7). Hyötylähtöinen politiikka eroaa nykyisestä siten, että korvaus maksettaisiin toimenpiteiden kustannusten korvaamisen sijaan sen perusteella, miten tilalla toteutetut toimenpiteet vaikuttavat mitattuun ympäristöhyötyyn. Viljelijät pitivät nykyistä ohjelmaa annettujen tietojen valossa parempana keinona parantaa ympäristön tilaa. Sitä pidettiin myös oikeudenmukaisempana kuin hyötylähtöistä ohjelmaa ja sen ajateltiin edellyttävän hyötylähtöistä ohjelmaa vähemmän valvontaa.

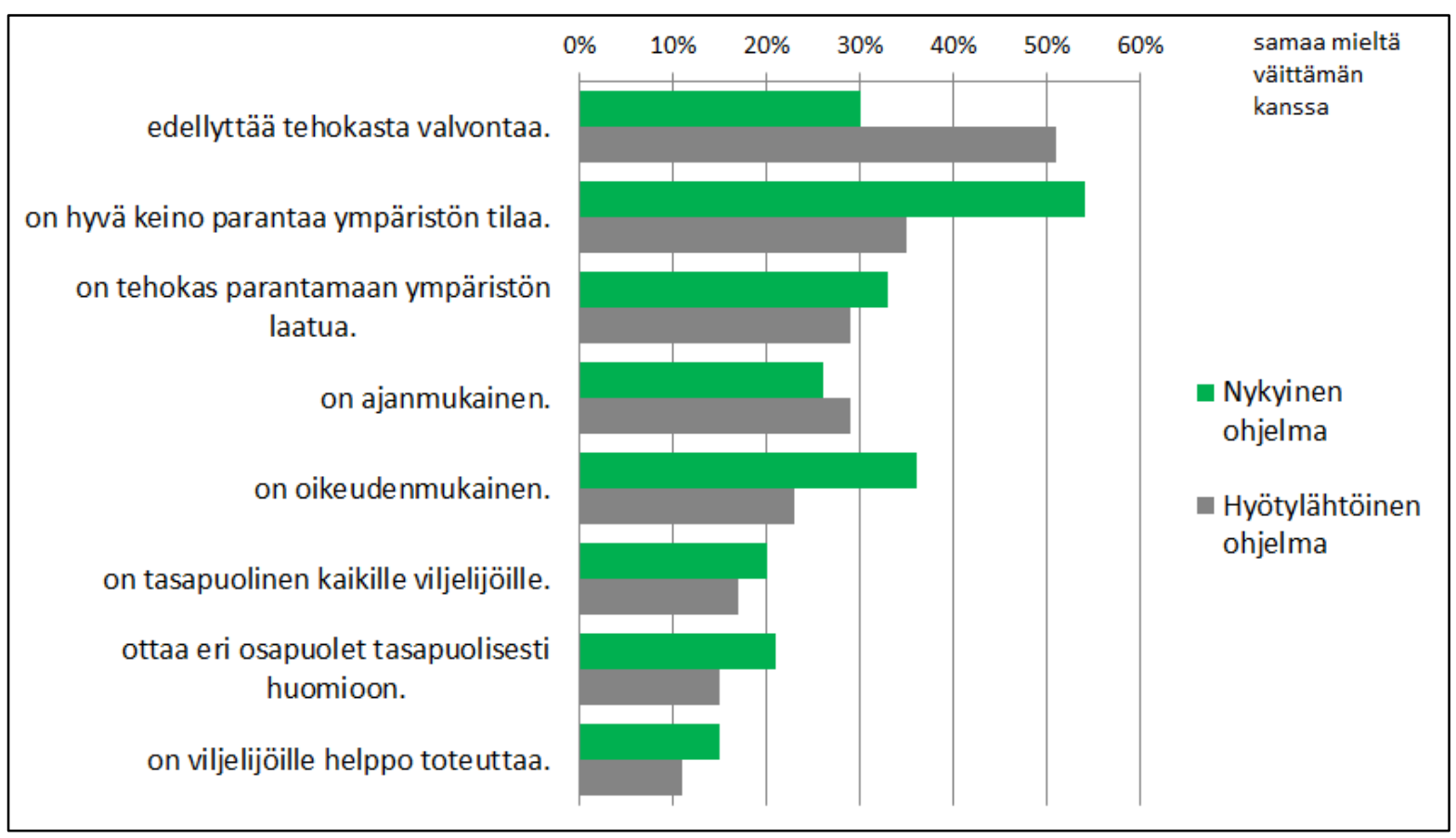

Kuva 7. Viljelijöiden suhtautuminen nykyiseen ja hyötylähtöiseen ympäristöohjelmaan. 
Hyötylähtöisen politiikan mahdollisuuksista keskusteltiin työpajassa. Kyselytutkimuksissa määritettyjen ekosysteemipalveluiden kysynnän ja tarjonnan perusteella työpajassa kartoitettiin keinoja, joilla ekosysteemipalveluiden tarjontaa voidaan ohjata tulevaisuudessa vastaamaan kysyntää. Työpajan osallistujat kokivat, että maatalouden ekosysteemipalveluiden kysyntä kasvaa tulevaisuudessa selvästi tarjontaa enemmän, mikäli tarjontaan ei vaikuteta sitä tukevalla politiikalla. Myös ekosysteemipalveluiden kysyntään voidaan vaikuttaa etenkin kannustamalla kuluttajia ekosysteemipalveluita tukeviin valintoihin ja vaikuttamalla viestinnällä kuluttajien asenteisiin. Hyötylähtöisten politiikkakeinojen nähtiin sopivan joidenkin ekosysteemipalveluiden tarjonnan edistämiseen, mutta joidenkin palveluiden osalta esimerkiksi hyödyn mittaaminen koettiin nykyisistä lähtökohdista liian hankalaksi. Hyötylähtöisen politiikan toimintaedellytysten perusteellisempi varmistaminen edellyttäisi käytännön kokeiluja, joiden perusteella saataisiin selville hyötylähtöisen politiikan toteuttamiskelpoisuus ja pystyttäisiin arvioimaan niiden vaikuttavuutta.

\section{Tulosten tarkastelu}

Sekä tuottajien että kuluttajien keskuudesta löytyy kiinnostusta sille, että maatalouden ympäristöpolitiikkaa kohdennetaan aikaisempaa voimakkaammin maatalousympäristöjen ekosysteemipalveluiden tuottamiseen. Noin 80 prosenttia kansalaisista on valmis tukemaan ekosysteemipalvelujen tuotantoa todennetusti tehostavia ympäristöohjelmia. Näin ollen on tärkeää, että koko ekosysteemipalvelukirjo tulisi otettua huomioon päätöksenteossa.

Esitetyt tulokset ovat ensimmäisiä kansallisia tuloksia maatalousympäristöjen keskeisten ekosysteemipalvelujen tarjonnasta ja kysynnästä. Aikaisemmat tutkimukset, joissa keskitytään maatalouden ekosysteemipalveluihin ovat osoittaneet kysyntä- ja tarjontatiedon merkityksen (Lima Santos ym. 2016). Muutamat tutkimukset ovat myös nostaneet esiin hyötylähtöisen politiikan suunnittelun sekä kysynnän että tarjonnan näkökulmasta (esim. Castro ym. 2014, Nieto-Romero ym. 2014, Zasada 2011, Huang ym. 2015). Aiemmissa tutkimuksissa on kuitenkin keskitytty usein yhteen tai muutamaan ekosysteemipalveluun ja useimmat aiemmat tutkimukset ovat kohdistaneet vain kysyntään, jättäen huomiotta tarjontapuolen (Chen ym. 2017). Hyötylähtöiseen politiikkaan suhtauduttiin kriittisesti viljelijöiden taholta. Joidenkin palveluiden osalta toimenpiteiden tuottaman hyödyn todentaminen koettiin haastavaksi. Kriittisyys kumpuaa osittain myös hyötylähtöisen politiikan ajattelumallin uutuudesta ja viljelijöiden kokemasta riskistä, kun ympäristöhyödykkeiden tuotannosta ei ole yhtä vahvaa tietopohjaa kuin perinteisten tuotteiden, ruoan ja kuidun.

\section{Johtopäätökset}

Politiikan suunnittelussa tulee painottaa niitä ekosysteemipalveluita, joita kansalaiset pitävät tärkeinä, mutta joiden tuotannossa koetaan olevan parantamisen varaa. Tällaisia ovat kasveja pölyttävien hyönteisten säilyminen, maisema, luonnontilaisten kasvi- ja eläinlajien sekä ekosysteemien säilyminen maatalousympäristössä sekä maatalouden kulttuuriperintö.

Viljelijöiden kiinnostus kohdistuu erityisesti maatalousmaan tuottokyvyn ylläpitämiseen. Koska viljelijöiden kiinnostus on korkealla tasolla, kohtuullisen pienellä politiikkasysäyksellä voidaan saada aikaan paljon tuloksia. Lisäksi maaperän tuottokyky liittyy moniin muihin ekosysteemipalveluihin, joten parantamalla tuottokykyä voidaan samalla muun muassa vähentää ravinteiden huuhtoutumista ja lisätä hiilen sitoutumista maatalousmaahan.

Ympäristöpolitiikan tehokkaassa kohdentamisessa tulisi löytää kohteet, joissa kuluttajien maksuhalukkuus ylittää tuottajien kompensaatiovaatimuksen. Tulokset kuitenkin osoittivat, että kompensaatiovaatimukset ylittävät makuhalukkuuden tässä tutkimuksessa tarkasteltujen neljän ekosysteemipalvelun kohdalla. Taustalla olevat oletukset kuitenkin vaikuttavat tulokseen. Jos laskennassa käytettäisiin nykyistä ympäristökorvausalaa pienempää hehtaarimäärää, maksuhalukkuus voisi ylittää kompensaatiovaatimukset. Tämä voisi olla jopa realistista, jos toimet kohdistuisivat 
uudessa politiikassa tehokkaammin alueille, jossa hyödyt ovat suurimmat.. Kansalaisten maksuhalukkuus ja viljelijöiden kompensaatiovaatimus ovat lähimpänä toisiaan maisemaan liittyvissä ekosysteemipalveluissa. Tämän perusteella erityisesti eläinten laiduntamisen lisäämiseen kannattaisi kohdistaa politiikan toimenpiteitä.

Kansalaisten maksuhalukkuus kohdistuu erityisesti biodiversiteettiin ja vedenlaatuun, mutta viljelijöiden kompensaatiovaatimus näiden ekosysteemipalveluiden tuotannon lisäämisestä oli korkea. Ratkaisuna on kehittää uusia keinoja kyseisten ekosysteemipalveluiden tuotannon kustannusten alentamiseen.

Lähes 30 prosenttia viljelijöistä oli valmiita tuottamaan palveluita kansalaisten keskimääräistä maksuhalukkuutta alemmalla korvaustasolla. Tuotannon tukea voitaisiinkin kohdentaa erityisesti näille viljelijöille. Näin osa viljelijöistä valitsisi tuotantosuunnakseen ekosysteemipalveluiden tuotannon, esimerkiksi maisemapalvelut tai biodiversiteetin.

Ekosysteemipalveluiden tuotannon kustannuksia voidaan kattaa myös osana ruoan hintaa. Tätä mahdollisuutta kannattaa tutkia lisää ja kehittää eteenpäin. Myös aktiivinen viestintä on tärkeää ekosysteemipalveluiden esiin nostamiseksi sekä hyötylähtöisen maataloudenympäristöpolitiikan hyväksyttävyyden lisäämiseksi.

Kun EU:n yhteistä maatalouspolitiikkaa uudistetaan, tulee Suomen aktiivisesti ajaa hyötylähtöisten politiikkakeinojen pilotointia ja mahdollisuuksia niiden laajempaan käyttöönottoon. Hyötylähtöinen, tuloksiin perustuva järjestelmä voidaan tuoda käytäntöön hyvin toteutettujen pilottien kautta. Jotta politiikkauudistukset olisivat kansalaisten mielestä hyväksyttäviä ja he olisivat valmiita maksamaan niistä, on tärkeää, että pilottien ympäristöhyödyt ovat todennettavissa. Viljelijöiden näkökulmasta katsottuna on tärkeää, että politiikkauudistuksesta aiheutuva hallinnollinen kuormitus pysyy kohtuullisena.

\section{Viitteet}

Ahtiainen, H. \& Pouta, E. 2011. The value of genetic resources in agriculture: a meta-analysis assessing existing knowledge and future research needs. International Journal of Biodiversity Science, Ecosystem Services \& Management 7: 27-3. https://doi.org/10.1080/21513732.2011.593557

Arovuori, K. \& Saastamoinen, O. 2013. Maatalouden ekosysteemipalveluiden luokittelu Suomessa. PTT työpapereita $155.23 \mathrm{~s}$. http://www.ptt.fi/julkaisut-ja-hankkeet/kaikki-julkaisut/classification-of-agriculturalecosystem-goods-and-services-in-finland.html

Castro, A. J., Verburg, P.H., Martín-López, B., Garcia-Llorente, M., Cabello, J., Vaughn, C.C. and López, E. 2014. Ecosystem service trade-offs from supply to social demand: A landscape-scale spatial analysis. Landscape and Urban Planning 132: 102-110. https://doi.org/10.1016/j.landurbplan.2014.08.009

Chen, Y., Zhang, Q., Liu, W. \& Yu, Z. 2017. Analyzing Farmers' Perceptions of Ecosystem Services and PES Schemes within Agricultural Landscapes in Mengyin County, China: Transforming Trade-Offs into Synergies. Sustainability 9: 1459. https://www.mdpi.com/2071-1050/9/8/1459

Grammatikopoulou, I., Pouta, E., Salmiovirta, M. \& Soini, K. 2012a. Heterogeneous preferences for agricultural landscape improvements in southern Finland. Landscape and Urban Planning 107: 181-191. https://doi.org/10.1016/j.landurbplan.2012.06.001

Grammatikopoulou I., Pouta E. \& Iho, A. 2012b. Willingness of farmers to participate in agri-environmental auctions in Finland. Food Economics 9: 215-230. https://doi.org/10.1080/2164828X.2013.845557

Grammatikopoulou, I., Pouta, E. \& Salmiovirta, M. 2013. A locally designed payment scheme for agricultural landscape services. Land Use Policy 32: 175-185. https://doi.org/10.1016/j.landusepol.2012.10.010 
Huang, J., Tichit, M., Poulot, M., Darly, S., Li, S., Petit, C. \& Aubry, C. 2015. Comparative review of multifunctionality and ecosystem services in sustainable agriculture. Journal of Environmental Management 149: 138-147. https://doi.org/10.1016/j.jenvman.2014.10.020

Iho, A., Lankoski, J., Ollikainen, M., Puustinen, M. \& Lehtimäki, J. 2014. Agri-environmental auctions for phosphorus load reduction: experience from a Finnish pilot. Australian Journal of Agricultural and Resource Economics 58: 205-222. https://doi.org/10.1111/1467-8489.12049

Lima Santos, J., Madureira, L., Ferreira, A.C., Espinosa, M. \& Gomez y Paloma, S. 2016. Building an empiricallybased framework to value multiple public goods of agriculture at broad supranational scales. Land Use Policy 53: 56-70. https://doi.org/10.1016/j.landusepol.2015.12.001

luke.fi. https://www.luke.fi/tietoa-luonnonvaroista/maatalous-ja-maaseutu/maatalouden-ekosysteemipalvelut/

Nieto-Romero, M., Oteros-Rozas, E., González, J.A. \& Martín-López, B. 2014. Exploring the knowledge landscape of ecosystem services assessments in Mediterranean agroecosystems: Insights for future research. Environmental Science and Policy 37: 121-133. https://doi.org/10.1016/j.envsci.2013.09.003

TEEB 2010. The Economics of Ecosystems and Biodiversity Ecological and Economic Foundations. Edited by Pushpam Kumar Earthscan, London and Washington. 456 p.

Tienhaara, A., Pouta, E. \& Ahtiainen, H. 2013. Consumers as conservers - could consumers' interest in a specialty product help to preserve endangered Finncattle? Agroecology and Sustainable Food Systems 37: 1017-1039. https://doi.org/10.1080/21683565.2013.820249

Zasada, I. 2011. Multifunctional peri-urban agriculture-A review of societal demands and the provision of goods and services by farming. Land Use Policy 28: 639-648. https://doi.org/10.1016/j.landusepol.2011.01.008 